UDC 159.953.2:37.015.3:681.518.54:621.39

DOI https://doi.org/10.24919/2308-4863/44-3-41

Nataliya CHEPELYUK, orcid.org/0000-0002-6822-9691

PhD, Associate Professor,

Associate Professor at the Linguistic Training Department State University of Intellectual Technologies and Communications (Odesa,Ukraine)natalach@gmail.com

\title{
TEACHING ESP COURSE FOR THE STUDENTS OF DIFFERENT LANGUAGE COMPETENCY WHO ARE MAJORING IN CYBERSECURITY
}

The article describes the current situation in terms of teaching ESP English (ESP - English for Specific Purposes) at a particular University - the State University of Intellectual Technologies and Communications (SUITC, Odesa, Ukraine) focusing on the general context in higher education in Ukraine in conditions of COVID-19 outlining certain problems, challenges and solutions. Moreover, the stages of the research in the frame of the Pilot Project (VSPP - Virtual Studying Pilot Project) at SUITC with Peace Corps of the United States of America in Ukraine are presented and the first results on testing the students of non-philological specialties majoring in Cybersecurity are provided along with the practical materials, namely an extract from a pre-test, post-test and a questionnaire for the students. An extended example of the teaching/learning process in online classes is presented based on the three-element classification of personality types: visual, audial, and verbal.

Furthermore, as higher educational institutions in our country partly have been working in class and partly online, we are looking at what exactly blended learning is (a particular example of working in this mode is suggested), and why it is important to implement this mode in Ukrainian universities.

In addition, we would like to share the experience of team-teaching with a native speaker as English as a lingua franca becomes more widespread, and the language is starting to be found in many different contexts, and one place in which it is now found is the virtual lecture hall not only in English lessons but during teaching other academic subjects as Programming, Higher Mathematics, Telecommunications etc.

We are also examining how this approach can be implemented into lectures, tutorials and seminars. In the article, we suggest the results of our research on teaching online and share the experience in working online with the first and second year ICT (ICT - Information and Communication Technologies) students in 2019-2022. Moreover, there are some recommendations and examples which language teachers might need to ensure the smooth running of their classes. The material will be useful for instructors of TEFL (Teaching of English as a Foreign Language), and for teachers and researchers who are interested in special problems for the learner.

Key words: blended learning, online instruction, information and communication technologies (ICT), TEFL.

Наталія ЧЕПЕЛЮК, orcid.org/0000-0002-6822-9691 кандидат педагогічних наук, доиент, доцент кафедри лінгвістичної підготовки Державного університету інтелектуальних технологій $і$ зв'язку (Oдеса, Україна) natalach@gmail.com

\section{ВИКЛАДАННЯ АНГЛІЙСЬКОЇ МОВИ ЗА ПРОФЕСІЙНИМ СПРЯМУВАННЯМ СТУДЕНТАМ РІЗНОГО РІВНЯ ВОЛОДІННЯ МОВОЮ, ЯКІ НАВЧАЮТЬСЯ ЗА НАПРЯМОМ «КІБЕРБЕЗПЕКА»}

У статті описується поточна ситуаџія з викладанням англійської мови за професійним спрямуванням (ESP - English for Specific Purposes) у конкретному закладі вищьӧ освіти - Державному університеті інтелектуальних технологій $і$ зв'язку (ДУІТЗ, Одеса, Украӥна) з акцентом на загальний контекст вищої освіти в Украӥні в умовах COVID-19. Також згадуються певні проблеми, виклики й шляхи їх розв'язання, а саме представляються результати дослідження щчодо навчання онлайн і досвід такої роботи зі студентами першого й другого курсів, які навчаються із широким застосуванням інформаційно-комунікаційних технологій у 2019-2022 роках. Крім того, пропонується низка рекомендацій і прикладів, які можуть знадобитися викладачам іноземної мови задля того, щчоб забезпечити безперервну роботу в умовах сучасної пандемї. Також розглянуті етапи дослідження 6 рамках пілотного проєкту «Віртуальне навчання» (VSPP Virtual Studying Pilot Project) у Державному університеті інтелектуальних технологій $і$ зв'язку спільно з організацією «Корпус Миру Сполучених Штатів Америки в Украӥні» й надаються результати тестування студентів нефілологічних спечіальностей, які навчаються за 
напрямом «Кібербезпека», що брали участь у вищезгаданому проєкті. Поряд із практичними матеріалом, а саме фрагментами вхідного тесту з англійської мови й посттесту, пропонується анкета для студентів, що охоплює низку питань стосовно онлайн-навчання. Наведено розширений приклад процесу викладання / навчання на онлайнзаняттях з урахуванням триелементної класифікаиії типів особистості: візуального, аудіального й вербального.

Оскільки вищі навчальні заклади в нашій краӥні частково праџюють в аудиторіях, а частково - онлайн, розглядається саме таке змішане навчання, а також окреслюється варіант відповіді на запитання, чому важливо впроваджувати такий режим роботи в українських університетах.

Крім того, пропонується досвід командної роботи - викладання та навчання з носієм мови, оскільки саме англійська мова як lingua franca стає все поширенішою у світі майже в усіх иаринах освіти й науки. Зокрема, сучасні віртуальні аудиторії впроваджуються не лише на заняттях з англійської мови, а й під час викладання інших навчальних предметів, як-от програмування, вища математика, телекомунікації тощьо. Ми також досліджуємо, як такий підхід можна втілити під час лекиійних занять і семінарів.

Матеріал може бути корисним як для викладачів TEFL (викладання англійської мови як іноземної), так і для викладачів і науковиів інших фахів.

Ключові слова: змішане навчання, онлайн-навчання, інформачійно-комунікаиійні технології (IKT), TEFL.

The problem setting. Teaching an ESP course (ESP - English for Specific Purposes) to students of different Language Competency, especially those majoring in ICT (Information and Communication Technologies) namely in Cybersecurity, can be a demanding task for university teachers. Such a course presupposes a unique combination of challenging activities on grammar, samples of linguistic analysis and thought provoking speaking and writing exercises, accompanied by engaging topics for discussion and extensive ESP vocabulary building which helps learners to master real life modern skills.

The COVID crisis has caused a complete rethinking of the delivery of education at all levels. With the necessity of social distancing to control the spread of the virus, many educational institutions have looked to online instruction as a means to continue to deliver the education they were contracted to provide (Herold, 2020). While earlier studies have addressed aspects of online learning (Brooks, 2003; Zhan, Mei, 2013; Tanner et al., 2009), none have addressed the problems of the current crisis that have necessitated the wholesale movement to online/distance learning then switching over to face to face mode and using the blended mode. This is especially true for internationally-directed learning because of the time differences.

The research analysis. The research focuses on the advantages of the course mentioned above for future ICT specialists using the examples of:

- textbook extract from Volume 1 "An Introduction to Cybersecurity in English", developed by teachers from SUITC, in collaboration with a PC volunteer of the US, which combines classic teaching techniques with current teaching methods;

- online Team-Teaching experience over two years in the conditions of the pandemic as a part of blended learning mode.

The article purpose. The aims of the article are:
- to show the results of the research in teaching ESP of ICT students with different levels of language competency using blended learning;

- to share the experience in the mode of blended learning and some results that students have displayed in terms of developing their productive and receptive language skills, some other sub-skills which we can encourage to improve while pushing them further towards a more native-like level of language use.

The main part. Currently one of the newest and most popular modes of teaching and studying is blended learning. As with all the latest educational methods and approaches, SUITC (State University of Intellectual Technologies and Communications) has a range of different tools to aid learning in general and make the language preparations more efficient and engaging. In this article, we will be looking at different activities to meet the students' needs and fulfill the tasks of the research mentioned above, whether we are teaching online or face-to-face. These activities are supposed to liven up the lessons and involve the students in the learning process in the conditions of the quarantine.

Those who have been teaching and studying using a possibility to involve a native speaker will value the idea of authentication while listening and speaking, and also implementing classical approach while reading and analyzing ESP texts, combined with vocabulary and grammar tasks, and will see a positive effect on their level of comprehension and use of English. Such realworld language, challenging activities and recycling of authentic language will build students' confidence in understanding context and communication of native and non-native speakers of English.

The United States Peace Corps in Ukraine, in its effort to continue their mission of providing assistance to educational process in our country after the evacuation of the Volunteers in March 2020, have developed a pilot program in cooperation with the Ukrainian Ministry of Education. The program, the 
Peace Corps Virtual Service Project, is an attempt to allow selected PC Volunteers to continue serving Ukraine from the United States. One of the areas of service to be attempted is TEFL at the university level. To this effect, the SUITC was selected due to the strong instructional program at the University set up by Dr. Douglas Lee Hall, Peace Corps Volunteer, and his counterpart, Dr. Chepelyuk, Assoc. Professor of English and Linguistics.

Dr. Hall has been at SUITC as a TEFL Volunteer teaching both English and IT for over three years and, in close cooperation with Dr. Chepelyuk, helped organize and start the Cybersecurity program SUITC, developing a textbook (Chepelyuk, Hall et al., 2019) and other materials not only to teach English, but to also teach the basics of ICT in general and Cybersecurity in particular. The textbook and materials have been used for over three years for in-person instruction and thus provided unit-based instruction that could be easily transferred to online instruction.

To that point, the authors of the course developed are proposing a study of the efficacy of international online instruction for teaching of English as a foreign language (TEFL) in the subject of Cybersecurity. The study is included not only measuring the efficacy of the instruction as per student satisfaction, but also the organizational structure of the classes and the platform for delivery.

The authors are fortunate to not only have a first year class of cybersecurity that is beginning study, but also a second year class that received in-person instruction during the 2019-2021 and 2021-2022 Academic Years. They have been providing invaluable input on both the good and bad aspects of online instruction.

The classes have been organized as follows:

1) the classes are organized into subgroups of 3-4 students with one student selected as Group Leader from within the group. The selection is based on the pre-test (see Appendix 1) created by Dr. Chepelyuk to establish the level of English proficiency of the student. Since Group Leaders are expected to help the members of their group not only with the material from the Cybersecurity class but also with English in general, students with a higher level of English are selected. Since their continued position as group leader is dependent upon their meeting the criteria of being Group Leader, a Group Leader may be replaced by another student;

2) the Group Leader acts as the liaison between a teacher and their particular group - submitting classwork, coordinating presentations, keeping track of attendance / compliance within their subgroup;

3) the platform for instruction is Zoom;
4) the platform for interaction between members of each group is the choice of the group;

5) the Group Leader is responsible for sending their group members the Zoom notifications and any other material sent from the teacher.

Instruction:

1) the first part of the lesson is instruction by the teacher. All students are required to be in attendance. They need to login on mute and with video. They need to login on time;

2) when the lecture is finished, the students break into their subgroups, leaving the Zoom meeting to join their group using whatever software they have an access or they have chosen, with the Group Leader remaining in the Zoom meeting with the teacher;

3 ) at the end of the class, the Group Leaders will report on the activities of their group and notify the teacher if all of their group attended or if anyone was missing;

4) students who wish to ask the teacher a direct question may log back into the Zoom meeting to do so or direct the question through their Group Leader.

In the Zoom meeting, students should label their Zoom entry as follows:

ZOOM Name Titles: GROUP LEADERS: CS Y\# GL\# their 1st name and last name; GROUP MEMBERS: CS Y\# G\# their first name and last name.

Because of the distance, the organization using Group Leaders provides not only a structure for the class but gives the students that chance for responsibility and leadership skills. In addition to the class time, Dr. Hall (only in a distance learning mode) and Dr. Chepelyuk meet with the Group Leaders on a periodic basis to answer any questions they may have and solve any problems that may arise either on a distance mode or in class when it possible according to the pandemic situation.

Conclusions. To judge the efficacy of the online instruction and the analysis of language accuracy and further language development, a student satisfaction survey (Zhan, Mei, 2013: 131-138) will be administered to the students in December 2021 and May 2022. The survey results of over 100 students will be compiled, analyzed, and reported to enhance the online experience of the students and success of the Peace Corps Virtual Service Project in meeting its in-country mission and goals. In addition, the students are monitored regularly in terms of their language accuracy and language development with necessary steps taken to correct any deficiencies and help in their language development.

Appendix 1. Pre Test (an extract, the complete Variant of the test is available online on You Tube Channel). 
TEST 1. Reading. Task 1. Read the texts below. For questions (1-5) choose the correct answer (A, B or C). Write your answers on the separate answer sheet.

Question 1. The term "computer" was actually first used to describe people who had the skills to "compute" mathematical problems quickly. The machines they used were "calculators" - mechanical machines that could be used to add, subtract, multiply, and divide more quickly and accurately than they could.

According to the extract above what did the term "computer" use to mean?

A) A machine that was able to solve the problems very fast.

B) A person who was good at counting.

C) A mechanical machine that was used to fulfill mathematical problems.

Question 2. Every device has a forerunner. Make a chart of the technology that was available to you and your friends in the story and what it was the forerunner of.

According to the instruction above it should be done:

A) A family tree.

B) A list of your friends.

C) A table of devices.

Question 3. Cybersecurity specialists work with all types of organizations to keep their computer information systems secure. They determine who requires access to which information, and then plan, coordinate, and implement information security programs. In addition, they help prevent attacks through their expertise and knowledge of databases, networks, hardware, firewalls and encryption. Cybersecurity analysts may also regulate access to computer files, develop firewalls, perform risk assessments and test data processing systems to verify security measures.

According to the extract above:

A) Information security specialists are responsible for keeping all the systems at an organization safe.

B) One of the main tasks of a cyber security specialist is to prevent any unauthorized intrusion into an organization's computer system.

C) Cybersecurity specialists create all hardware and software to protect an organization where they work.

Question 4. The road to becoming a cybersecurity specialist is a hard road requiring much determination and concentration. The payoff is a highly paid, wellregarded occupation that will be in demand for the foreseeable future.

As of May 2014, the average annual salary for the category of professionals that includes cybersecurity specialists was US\$91,600, the United States Bureau of Labor Statistics reported. The top $10 \%$ of wage earners earned more than US\$140,000. In a 2017 survey of salaries, the average salary had risen to US $\$ 107,133$, a nearly $17 \%$ rise in just three years.

According to the extract above:

A) An average cybersecurity specialist usually earns $10 \%$ more than any other professional in the IT annually.

B) The average salary in cybersecurity area has been growing permanently.

C) The top managers in the profession earn $10 \%$ more than their subordinates do.

Question 5. We live in an increasingly dangerous world. All types of security - physical and electronic are becoming more important with data theft, hacking, viruses, and other activities that put a company's assets at risk. For those reasons, the demand for cybersecurity specialists has skyrocketed. A Forbes magazine article (January 2016) noted that there was a demand for 1 million cybersecurity specialists in 2016. It is expected to grow to six million by 2019. Unfortunately, these specialists are not being created fast enough to meet the demand. This means high salaries and secure employment for those in cybersecurity.

According to the extract above:

A) More and more cybersecurity specialists are needed at a job market.

B) It is extremely vital to increase the level of salaries in the cybercecurity field.

C) The number of cybersecurity specialists increased from 1 million, in 2016, up to 6 million in 2019.

Appendix 2 (6). Sample Student Satisfaction Questionnaire.

Question Sample on E-Learning: Student Satisfaction

NOTE: please keep in mind this is just a sample, actual SurveyShare templates use pull down menus, checkboxes and radio buttons for user responses.

1) Were you in English for Cybersecurity Year 1 or Year 2?

2) Did you access the course from your home computer, work or school computer or both?

3) Overall, how satisfied or dissatisfied were you with the course?

Very Dissatisfied

Dissatisfied

Neither Satisfied or Dissatisfied

Satisfied

Very Satisfied

Don't Know

4) How satisfied or dissatisfied were you with the content of the course?

Very Dissatisfied 
Dissatisfied

Neither Satisfied or Dissatisfied

Satisfied

Very Satisfied

Don't Know

5) How satisfied or dissatisfied were you with the format of the course?

Very Dissatisfied

Dissatisfied

Neither Satisfied or Dissatisfied

Satisfied

Very Satisfied

Don't Know

6) How satisfied or dissatisfied were you with the ability to navigate through the course?

Very Dissatisfied

Dissatisfied

Neither Satisfied or Dissatisfied

Satisfied

Very Satisfied

Don't Know

7) How satisfied or dissatisfied were you with the online help features of the course?

Very Dissatisfied

Dissatisfied

Neither Satisfied or Dissatisfied

Satisfied

Very Satisfied

Don't Know

8) How satisfied or dissatisfied were you with the download time for the course pages?

Very Dissatisfied

Dissatisfied

Neither Satisfied or Dissatisfied

Satisfied

Very Satisfied

Don't Know

9) How satisfied or dissatisfied were you with the online interaction you had with the instructor?

Very Dissatisfied

Dissatisfied

Neither Satisfied or Dissatisfied

Satisfied

Very Satisfied

Don't Know

No Online Interaction Possible
10) How satisfied or dissatisfied were you with the amount of online interaction you had with other students in this course?

Very Dissatisfied

Dissatisfied

Neither Satisfied or Dissatisfied

Satisfied

Very Satisfied

Don't Know

No Online Interaction Possible

Please tell us how much you agree or disagree with the following.

11) The course instructor was accessible to answer questions or give feedback.

Very Dissatisfied

Dissatisfied

Neither Satisfied or Dissatisfied

Satisfied

Very Satisfied

Don't Know

12) The presentation of course topics was clear.

Very Dissatisfied

Dissatisfied

Neither Satisfied or Dissatisfied

Satisfied

Very Satisfied

Don't Know

13) The requirements for completion of the course were clearly outlined.

Very Dissatisfied

Dissatisfied

Neither Satisfied or Dissatisfied

Satisfied

Very Satisfied

Don't Know

14) How many e-learning courses have you participated in including this course?

$15)$ What is your gender?

Male / Female

16) What is your age?

17) What is your total household income?

18) What is the highest level of education you have completed?

19) Do you want to participate in another online cybersecurity class next semester?

Yes / No / Don't Know

BIBLIOFRAPHY

1. Herold B. The Scramble to Move America's Schools Online. March 27, 2020. Education Week, October 1, 2020. URL: https://www.edweek.org/ew/articles/2020/03/26/the-scramble-to-move-americas-schools-online.html (Accessed: 01.10.2020).

2. Brooks L. How the Attitudes of Instructors, Students, Course Administrators, and Course Designers Affects the Quality of an Online Learning Environment. Online Journal of Distance Learning. 2003. URL: https://www.westga.edu/ distance/ ojdla/winter64/brooks64.htm (Accessed: 30.09.2020). 
3. Zhan Z., Mei H. Academic self-concept and social presence in face-to-face and online learning: Perceptions and effects on students' learning achievement and satisfaction across environments. Computers \& Education. Vol. 69. November 2013. P. 131-138.

4. Business Faculty and Undergraduate Students' Perceptions of Online Learning: A Comparative Study / J. Tanner et al. Journal of Information Systems Education. Spring 2009. Vol. 20. Issue 1. P. 29-40.

5. An Introduction to Cybersecurity in English / N. Chepelyuk, D. Hall et al. Vol. 1. O. S. Popov Academy of Telecommunications, Odesa, Ukraine, 2019.

6. E-Learning: Student Satisfaction Sample Template. University of Hawaii, Honolulu, Hawaii. URL: https://www.hawaii.edu/its/surveyshare/surveyshare_examples/studentsatisfaction.htm (Accessed: 30.10.2020).

\section{REFERENCES}

1. Herold B. “The Scramble to Move America's Schools Online”, March 27, 2020, Education Week, October 1, 2020. URL: https://www.edweek.org/ew/articles/2020/03/26/the-scramble-to-move-americas-schools-online.html (Accessed 1 Oct 2020).

2. Brooks L. "How the Attitudes of Instructors, Students, Course Administrators, and Course Designers Affects the Quality of an Online Learning Environment”, Online Journal of Distance Learning, 2003. URL: https://www.westga.edu/ distance/ ojdla/winter64/brooks64.htm (Accessed 30 Sep 2020).

3. Zhan Z., Mei H., "Academic self-concept and social presence in face-to-face and online learning: Perceptions and effects on students' learning achievement and satisfaction across environments", Computers \& Education, Volume 69, November 2013, pp. 131-138.

4. "Business Faculty and Undergraduate Students' Perceptions of Online Learning: A Comparative Study" / J. Tanner et al. Journal of Information Systems Education, Vol. 20, Iss. 1, (Spring 2009). pp. 29-40.

5. An Introduction to Cybersecurity in English / N. Chepelyuk, D. Hall et al. Volume 1, O. S. Popov Academy of Telecommunications, Odesa, Ukraine, 2019.

6. E-Learning: Student Satisfaction Sample Template, University of Hawaii, Honolulu, Hawaii. URL: https://www.hawaii.edu/its/surveyshare/surveyshare_examples/studentsatisfaction.htm (Accessed 30 Sep 2020). 